UDC 614.7

\title{
HYGIENIC ESTIMATION OF THE STRUCTURE AND LEVEL OF THE PROFESSIONAL RISK OF MAIN PROFESSIONS IN PRODUCTION OF RAILWAY COACHES
}

\author{
V.A. Synoda \\ SBEI HPE “Tver State Medical University” Ministry of Health of the Russian Federation, \\ Russian Federation, Tver, 4 Sovetskaya St., 170100
}

The article considers of results of hygienic estimation of the conditions of the labor, gravity and tension of the labor process in the main subdivisions production of railway coaches. The result of analysis is contains the estimation of qualifications of workers places, frequencies of the traumas and diseases of worker.

The priority disadvantage production factors for the health risk of worker are determined. Individual professional risk for leading professions in production of railway coaches at periods is evaluated before and after of economical production principle is introducing.

Key words: the hygienic estimation, condition of the labor, production factors, professional risk, production of railway coaches

The health of the working-age population is the component part of human capital assets and in this relation its preservation is a priority task [1].

Recently a number of productions of the machine-building industry, in particular, at the aviation machine-building enterprises (Salyut OJSC, Moscow, OJSC Voronezh Joint-Stock Aircraft Company, Voronezh), as well as for the representatives of the separate professions (workers of the transport and process machines and mechanisms, machine tool operators, electric and gas welders of the different machine-building enterprises (LLC Moscow Plant of Specialized Cars)) test the unified methods for assessing the individual and group occupational risk (GOR), taking into account the actual working conditions, probability of injuries, health status of the workers, detected occupational diseases and industrial accidents [2-4, $6]$.

The casting and forging shops as well as the manual arc welding and recently the semiautomatic and automatic hidden arc welding are highly developed and widely used in the transport machine building, including at the enterprises producing the railway coaches. The enterprises producing the railway coaches also differ by the development of shops for the metal (halvanized) and nonmetal (paint) coatings the availability of which has the important hygienic meaning.

At the same time the production of railway coaches which has the own specific character of production processes and is characterized by the hazardous and harmful working conditions did not perform any hygienic studies on the occupational risk assessment.

In addition, a number of machine-building productions, including Tver Coach Building Works (TCBW OJSC), implements a new production system "Lean production" aimed at the solution of production and economic tasks on increasing the labor productivity, decreasing the prime costs of products, reducing the terms of delivery, decreasing the expenses and production losses, i.e. performs the optimization of production and labor expenses that also makes actual the conduction of studies on assessing the profile and level of the occupational risk for workers.

The study was aimed at the assessment of hygienic efficiency in relation to implementing the lean production principles to the field of labor protection and decreasing the occupational risk for workers. In this relation we solved the tasks on the quantitative determination of the occupational risk for workers and the contribution of the production factors to its formation (risk profile determination).

Materials and methods of study. For the quantitative assessment of the individual occupational risk (IOR) we used the main provisions of "Methods for calculating the individual occupational risk depending on the working conditions and the health of worker" and "Methods for calculating the integral indicators of the level of occupa-

(C) Synoda V.A., 2015

Synoda Vitaly Aleksandrovich - Doctor of Medicine, Professor, Department of Hygiene and Ecology, Head of Rospotrebnadzor in the Tver region, Chief State Sanitary Doctor of the Tver region (e-mail: info @ 69. rospotrebnadzor.ru; tel.: 8 (4822) 34-22-11). 
tional risk in the organization" (developed by Klinsk Institute of Labor Protection and Conditions) [5] as well as the initial data of TCBW OJSC, including the results of attestation of the working places, number of inuries and newly detected cases of the occupational diseases for the workers of certain orofessions. In particular, we determined the indicator of harmfulness of the working conditions at the working place which characterizes the total harmfulness of the working conditions at the working place (the designation of indicator is $\mathrm{HI}$ ). The HI was calculated depending on the classes of working conditions established for all the factors acting at the working place.

To obtain the group profile of the occupational risk at the main shop subdivisions of the coach producing industry having assessed the level of impact for each harmful factor with determining the calss of the working conditions the each class of working conditions obtained the points (classes 1 and $2-2$ points; $3.1-4,3.2-8,3.3-16,3.4-32,4-64$ points). In future the points for the shop subdivision or one certain profession were summarized and the specific weight of points for each factor in percent was calculated. The calculation of share for each factor in the aggregate impact of unfavorable working conditions provided the profile of occupational risk.

The individual occupational risk (IOR) of worker as the single numerical value depending on the working conditions and the condition of health was calculated by the multiplication of the sum of weighted values of parameters (working conditions, working experience of worker in the harmful and (or) hazardous working conditions, age and condition of health) reduced to the relative values by the indicators of traumatism (TI) and morbidity (MI) at the working place.

The assessment of occupational risk is performed for 47 professions of 4 main shop subdivisions of the coach building works (frame and body shop, coach assembly shop, casting shop, cold press shop).

The main volume of studies on the hygienic assessment of production environment, working conditions and occupational risk was condiventionally divided into two periods: the first - before the implementation of the lean production princi- ples (studies of 1997-2009), the second - during and at the end of the lean production principles implementation (2010-2013).

Results and their discussion. According to the results of attestation of the working places and the data of the state sanitary and epidemiological surveillance for 1927-2009 it is established that the working conditions of the main shops at TCBW OJSC (frame and body shop, coach assembly shop, casting shop, cold press shop) are assessed as the harmful and hazardous and forming the risks to the health (class 3 and class 4). The technological process is accompanied by the emission to the air of working area of highly hazardous chemical substances and the impact of physical factors (noise, total vibration, thermal radiation) exceeding the hygienic standards (maximum permissible concentration, maximum permissible level).

Based on the quantitative assessment of the working conditions for the leading professions of the coach building industry it is established that among four considered shop subdivisions the most unfavorable situation exists in the casting shop. The profile of occupational risk in this shop is represented by the contribution of the following production factors: the first rank place is occupied by the unfavorable microclimate $(22.2 \%)$, further are the impacts of chemical factor $(21.5 \%)$ and noise (20.5\%) (table 1).

According to the contribution to the occupational risk value the frame and body shop is dominated by the severity of labor $(28.2 \%)$, chemical factor $(18.3 \%)$ and noise $(15.5 \%)$; the coach assembly shop - by the chemical factor $(24.1 \%)$, severity of labor (18.8\%) and noise $(15.5 \%)$; the cold press shop - by the noise $(29.5 \%)$, chemical factor (28.2\%) and vibration (15.4\%).

Assessment of the indicator of harmfulness (HI) allowed for detecting the professions of the highest risk and ranking the professions under the integral indicator of harmfulness and hazard. The threshold assessment under the level of hazard and harmfulness (HI >30, highy hazardous harmfulness, rank 1) was attributed to two professions of the casting shop - cupola melter and caster $(\mathrm{HI}=36)$, at the leading contribution to the harmfulness indicator of the microclimate characteristics (74.4\%) (table 2).

Table 1

The profile of occupational risk at the main shop subdivisions

\begin{tabular}{|c|c|c|c|c|c|c|c|c|}
\hline \multirow[b]{2}{*}{ Shop } & \multirow{2}{*}{$\begin{array}{l}\text { The sum of } \\
\text { points for } \\
\text { all the fac- } \\
\text { tors (Vf) }\end{array}$} & \multicolumn{7}{|c|}{ Specific weight of the risk factors to the sum of points for all the shop professions, $\%$} \\
\hline & & $\begin{array}{l}\text { chemical fac- } \\
\text { tor }\end{array}$ & noise & vibration & $\begin{array}{l}\text { microcli- } \\
\text { mate }\end{array}$ & $\begin{array}{l}\text { illumina- } \\
\text { tion }\end{array}$ & $\begin{array}{l}\text { severity of } \\
\text { labor }\end{array}$ & $\begin{array}{c}\text { intensity of } \\
\text { work }\end{array}$ \\
\hline Frame and body shop & 284 & 18,3 & 15,5 & 9,9 & 6,3 & 8,5 & 28,2 & 13,4 \\
\hline
\end{tabular}




\begin{tabular}{|l|c|c|c|c|c|c|c|c|}
\hline Coach assembly shop & 224 & 24,1 & 17,0 & 11,6 & 8,9 & 8,9 & 18,8 & 10,7 \\
\hline Casting shop & 792 & 21,5 & 20,5 & 12,6 & 22,2 & 5,8 & 11,4 & 6,1 \\
\hline Cold press shop & 156 & 28,2 & 29,5 & 15,4 & 6,4 & 6,4 & 7,7 & 6,4 \\
\hline
\end{tabular}

Table 2

Ranking of professions of the coach producing industry under the indicator of harmfulness (HI) of the working conditions

\begin{tabular}{|c|c|c|}
\hline $\begin{array}{c}\text { Characterization of } \\
\text { harmfulness and hazard } \\
\text { (rank) depending on HI } \\
\text { value }\end{array}$ & \begin{tabular}{|c|} 
Harmfulness \\
indicator \\
value $(\mathrm{HI})$ \\
points
\end{tabular} & $\begin{array}{l}\text { Professions of the coach producing industry, their indicator of harmfulness (HI, points), } \\
\text { leading factor and its specific weight in the sum of harmfulnesses }(\%)\end{array}$ \\
\hline $\begin{array}{l}\text { Highly hazardous (rank } \\
\text { 1) }\end{array}$ & $\begin{array}{l}\text { More than } \\
30\end{array}$ & $\begin{array}{l}\text { Cupola melter }(\mathrm{HI}=36 \text {, microclimate, } 74.4 \%) \text {; } \\
\text { Caster }(\mathrm{HI}=36 \text {, microclimate, } 74.4 \%)\end{array}$ \\
\hline Hazardous (rank 2) & $15-30$ & $\begin{array}{l}\text { Painter, coach assembly shop (HI=24, chemical factor, } 51.6 \%) \text {; } \\
\text { Electric welder of manual welding }(\mathrm{HI}=23 \text {, severity of labor, } 53.3 \%) ; \\
\text { Metal cleaner (HI=22, noise, } 55.2 \%) \text {; } \\
\text { Emery wheel operator (HI=21, noise, } 28.6 \%) \text {; } \\
\text { Press operator of machine molding, casting shop (HI=20, vibration, } 59.3 \% \text { ); } \\
\text { Boxman (HI=16, chemical factor, } 34.8 \%) \text {; } \\
\text { Electric welders on the automatic machines (HI=15, intensity of work, } 36.4 \%)\end{array}$ \\
\hline $\begin{array}{l}\text { Unacceptably harmful } \\
\text { (rank 3) }\end{array}$ & $7-14$ & $\begin{array}{l}\text { Emeery wheel operator }(\mathrm{HI}=14, \text { noise, } 19.0 \%) \\
\text { Dresser }(\mathrm{HI}=12 \text {, noise, } 42.1 \%) \text {; } \\
\text { Dresser of heavy castings }(\mathrm{HI}=12 \text {, noise, } 42.1 \%) \\
\text { Oxygen-cutting operator }(\mathrm{HI}=10 \text {, noise, } 47.1 \%) \\
\text { Maintenance technician }(\mathrm{HI}=9 \text {, noise, } 50.0 \%) ; \\
\text { Casting technician }(\mathrm{HI}=8 \text {, chemical factor, } 26.7 \%) \text {; } \\
\text { Sand mixer }(\mathrm{HI}=8 \text {, chemical factor, } 53.3 \%) \text {; } \\
\text { Oxygen-cutting operators, welders on the contact welding machines }(\mathrm{HI}=8 \text {, chemical } \\
\text { factor, } 26.7 \%)\end{array}$ \\
\hline Very harmful (rank 4) & $3-6$ & 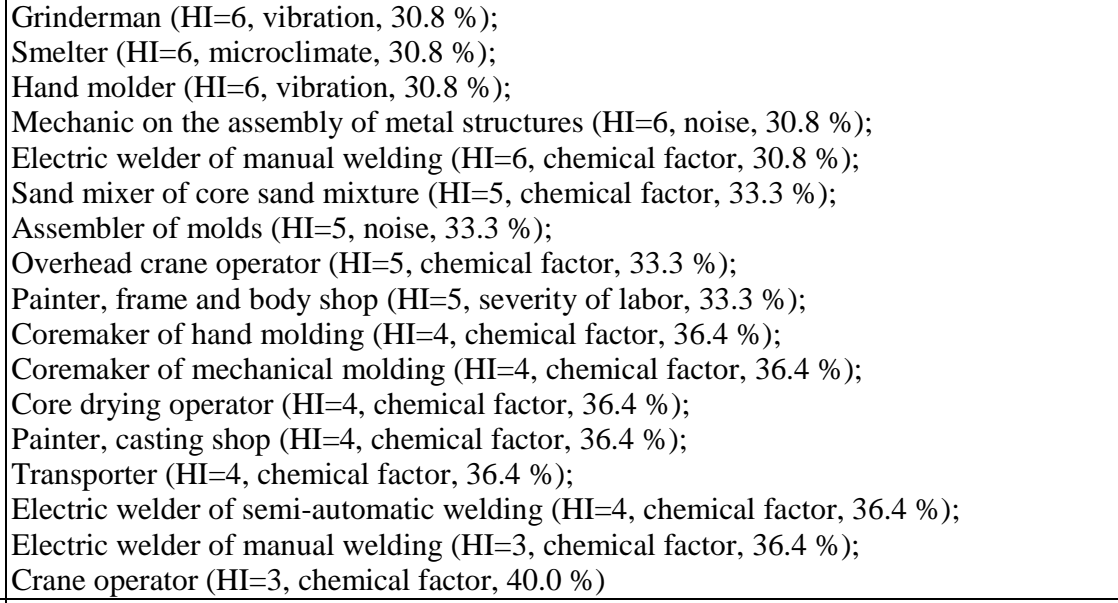 \\
\hline Harmful (rank 5) & $1-2$ & $\begin{array}{l}\text { Upholsterer and gluer of rubber items }(\mathrm{HI}=2 \text {, chemical factor, } 22.2 \%) \text {; } \\
\text { Shearer on machine saws }(\mathrm{HI}=2, \text { noise, } 22.2 \%) ; \\
\text { Metal shearer (HI=2, noise, } 22.2 \%) \text {; } \\
\text { Mechanician on the repair and maintenance of ventilation (HI=2, chemical factor, } 42.1 \\
\%) \text {; } \\
\text { Mechanicians of mechanical assembly work (HI=2, vibration, } 22.2 \%) \text {; } \\
\text { Polisher (HI=2, chemical factor, } 22.1 \%) \text {; } \\
\text { Installer of sanitary and technical systems (HI=1, noise, } 25.5 \%) \text {; } \\
\text { Assembling fitter of assembly operations (HI=1, noise, } 25.5 \%) ; \\
\text { Assembler of wooden items (HI=1, noise, } 25.5 \%) ; \\
\text { Wireman mechanician (HI=1, noise, } 25.5 \%) ; \\
\text { Mechanicians-tool makers, grindermen }(\mathrm{HI}=1 \text {, noise, } 25.5 \%)\end{array}$ \\
\hline
\end{tabular}

The professions of painter (coach assembly from 15 to 24 points - have the hazardous level of shop), electric welder of manual welding (frame and the occupational harmfulness (HI from 15 to 30, body shop), metal cleaner (casting shop), emery rank 2). wheel operator (cold press shop), coremaker of mechanical molding (casting shop), electric welder on the automatic machines (frame and body shop) - HI

Herewith, for each of these professions the leading risk factor was different (chemical factor, severity of labor, noise, vibration, intensity) and its 
contribution to the value of occupational harmfulness varied from 34.8 to $59.3 \%$.

The unacceptably harmful working conditions (HI from 7 to 4, rank 3) are specific for the profession of the emery wheel operator of the frame and body shop, leading factor - noise $(19.0 \%$ of contribution to $\mathrm{HI}$ ), dresser of casting shop, leading factor - noise $(42.1 \%)$, dresser of heavy castings of casting shop, leading factor - noise $(42.1 \%)$, oxygen-cutting operator of the cold press shop, leading factor - noise $(47.1 \%)$, maintenance technician of casting shop, leading factor - noise (50.0 $\%$ ), casting technician, sand mixer of casting shop, leading factor - chemical (26.7 and $53.3 \%$, respectively), as well as the oxygen-cutting operator, welder on the contact welding machines of the frame and body shop, leading factor - chemical $(26.7 \%)$.

The most of professions are included into very harmful under the HI value (HI from 3 to 6, rank 4): grinderman (coach assembly shop), smelter, hand molder (casting shop), mechanics on the assembly of metal structures (frame and body shop), electric welder of manual welding (cold press shop), sand mixer of core sand mixture, assembler of molds (casting shop), overhead crane operator, painters (frame and body shop), coremaker of hand molding, coremaker of mechanical molding, core drying operator, painter, transporter (casting shop), electric welder of semi-autonatic welding (cold press shop), electric welder of manual welding, crane operator (casting shop).

The other considered professions under the harmfulness indicator are included into the harmful working conditions (HI from 1 to 2 ).

Moving to the assessment of the individual occupational risk (IOR) for workers of the leading professions of the coach-building industry it should be noted that IOR means the probability of the loss of health or death associated with the performance by worker of duties under the labor agreement (contract), depending on the working conditions at his/her working place and his/her condition of health.

Since the practices use the notions of the number of injuries for the expired year and the number of newly detected cases of occupational diseases for the expired year, to assess the risk we used the data of TCBW OJSC. The highest traumatism was observed in the frame and body shop. Among the professions of electric welder on automatic macines, mechanic on the assembly of metal structures, electric welder of manual welding, mechanician of mechanical assembly work, oxygen-cutting operator, welder on the contact welding machines, mechanician-tool maker, grinderman we registered 1 to 3 cases of traumatism per year with the severity of the consequences of injury (under the duration of VUT) of not more than 1 month. Among some professions of workers of the other shops we also recorded the traumatism from 1 to 2 cases per year with the severity of the consequences of injury under the duration of VUT of not more than 1 month. The coefficient which accounts the number of injuries (Ks) varied from 1.1 to 1.3 ; the severity of the consequences of injury $(\mathrm{Kt})-1$. The morbidity indicator (MI) value for all the professions was accepted as 1 .

It is established that IOR indicator for the main professions of the coach building production is within the range from 0.57 to 0.90 that according to the interval scale of the individual occupational risk belongs to very high risk (table 3).

Herewith the highest indicators of the individual occupational risk are observed in the casting shop for the professions of caster (0.90), cupola melter $(0.81)$, metal cleaner (0.79); in the frame and body shop for the professions of electric welder of manual welding (0.79), emery wheel operator (0.79), mechanic on the assembly of metal structures (0.78); in the cold press shop for the profession of emery wheel operator (0.78) (fig. 1).

The smallest IOR values are obtained for the professions of crane operator (casting shop) -0.58 , upholsterer and gluer of rubber items and mechanician on the repair and maintenance of ventilation (coach assembly shop) 0.57 , but they also belong to very high risk that evidences on the necessity of fundamental improvement of the working conditions in the coach-building production.

Very high level of risk is explained by that the most of professions under the results of the working places attestation have 2 to 4 factors with the class of harmful working conditions $(3.1-3.4)$.

$$
\text { Table } 3
$$

The indicators of individual occupational risk for the main professions of coach-building production

\begin{tabular}{|l|l|}
\hline Subdivision and profession & $\begin{array}{c}\text { Range of the individual occupational risk } \\
\text { (IOR) values }\end{array}$ \\
\hline
\end{tabular}




\begin{tabular}{|l|c|}
\hline $\begin{array}{l}\text { Frame and body shop: } \\
\text { electric welder on the automatic machines, mechanics on the assembly of metal struc- } \\
\text { tures, electric welders of manual welding, mechanicians of mechanical assembly } \\
\text { work, oxygen-cutting operators, welder on the contact welding machines, mechani- } \\
\text { cian-tool maker, grinderman, emery wheel operator, overhead crane operator, painter }\end{array}$ & $0,59-0,73$ \\
\hline $\begin{array}{l}\text { Coach assembly shop: } \\
\text { painter, installer of sanitary and technical systems, upholsterer and gluer of rubber } \\
\text { items, assembling fitter of assembly operations, assembler of wooden items, wireman } \\
\text { mechanician, grinderman, shearer on machine saws, metal shearer, mechanician on } \\
\text { the repair and maintenance of ventilation }\end{array}$ & $0,57-0,73$ \\
\hline $\begin{array}{l}\text { Casting shop: } \\
\text { boxman, coremaker of hand molding, coremaker of mechanical molding, core drying } \\
\text { operator, sand mixer of core sand mixture, smelter, cupola melter, caster, hand } \\
\text { molder, mechanical molder, casting technician, assembler of molds, dresser, dresser } \\
\text { of heavy castings, metal cleaner, casting technician, painter, transporter, sand mixer, } \\
\text { electric welder of manual welding, crane operator, maintenance technician }\end{array}$ & \\
\hline $\begin{array}{l}\text { Cold press shop: } \\
\text { emery wheel operator, oxygen-cutting operator, polisher, electric welder of manual } \\
\text { welding, electric welder of semi-automatic welding }\end{array}$ & $0,58-0,90$ \\
\hline
\end{tabular}

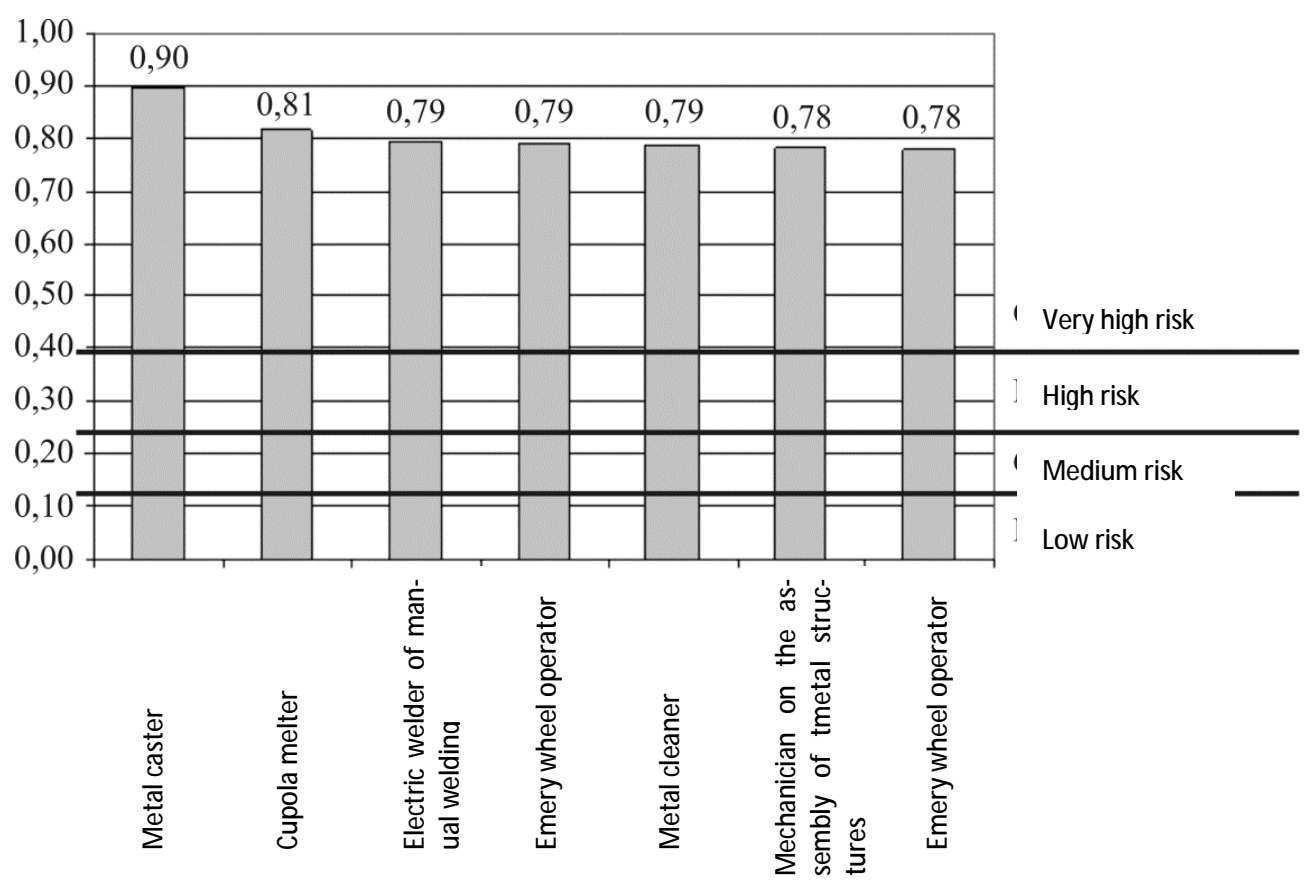

Fig. 1. Indicators of the individual occupational risk (IOR) as of 2006-2009 before the lean production principles implementation (dimensionless value)

During 2010-2013 the enterprise actively implements the lean production principles covering such labor protection issues critically important in relation to hygiene which resulted in decreasing the impact of the production risk factors, improving the comfort of staff at the working place, reducing the risks of accidents and occupational diseases.

In this relation the generelazing assessment of the working conditions is performed under a number of criteria by the comparison of two periods: before and after the lean production principles implementation which resulted in the re-attestation of working places covered by the measures taken at the pilot ares (in 20107 pilot areas or $11 \%$ of working places, in 2011 - other 15 areas or $29 \%$ of working places, in $2012-50 \%$ of working places).

In general, for 4 shop subdivisions we observed the positive dynamics in relation to the decrease of working places not meeting the hygienic standards under the content of vapor and gases, from 81.8 to $61.4 \%$, noise - from 75.0 to $72.7 \%$, vibration - from 62.3 to $51.0 \%$, indicators of microclimate - from 22.6 to $16.5 \%$, illumination from 61.8 to $50.7 \%$ (fig. 2). 


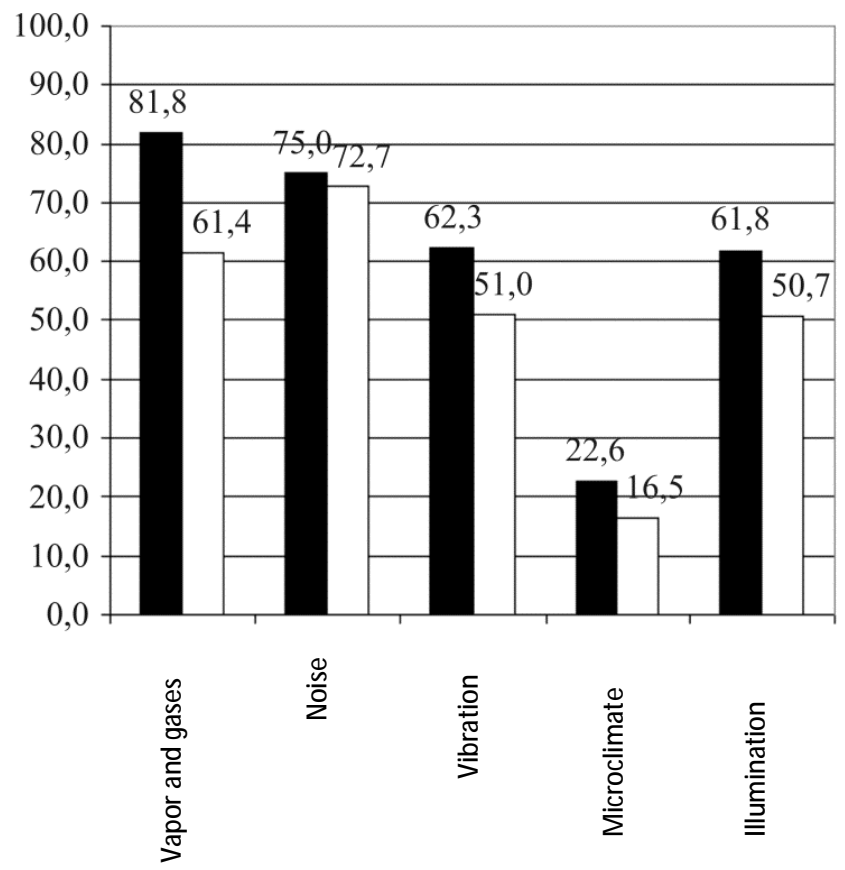

Before the lean production principles implementation (2006-2009)

After the lean production principles implementation (2010-2013)

Fig. 2. Specific weight of working places not meeting the hygienic standards, $\%$

The efficiency of measures taken within the lean production principles implementation is eveidenced by the changes in relation to the improvement of many priority indicators whih characterize the working conditions at the separate shop subdivisions. Especially clear it is traced under the average and maximum values of indicators. Thus, at the working places of the frame and body shop the maximum level of noise is decreased from 98 to $82.5 \mathrm{dBA}$; currently the average value of this indicator is $78.9 \mathrm{dBA}$ and complies with maximum permissible level. The maximum level of vibration decreased from 114 to $110 \mathrm{~dB}$ and now it complies with standard (maximum permissible level $=112$ $\mathrm{dB})$ at all the working places of the shop. The significant decrease in the welding aerosol concentration is achieved due to the implementation of new supply and exhaust ventilation systems and reequippment of working places at the welding stations: the maximum value of concentration decreased from 30.09 to $3.82 \mathrm{mg} / \mathrm{m}^{3}$, average value from 16.02 to $3.62 \mathrm{mg} / \mathrm{m}^{3}$.

The level of noise was also decreased at the working places of the coach assembly shop; the maximum value of it decreased from 92 to 79 $\mathrm{dBA}$, average - from 76.7 to $75.0 \mathrm{dBA}$, the maximum value of vibration level decreased from 119 to $111 \mathrm{~dB}$, average - from 95 to $89 \mathrm{~dB}$. The content of xylene (dimethylbenzene), toluene (methyl benzene) and acetone in the air of working zone was decreased. In addition, under the xylene content we observed the exceeding of the maximum permissible concentration in the air of working zone at the production areas where the painters are working.

The casting shop due to the specific character of production preserves the problems in relation to the level of noise and vibration, content of carbon oxide, ammonia and abrasive dust in the air of working zone as well as the parameters of microclimate.

For the cold press shop we achieved the decrease in the concentrations of abrasive dust maximum values from 19.66 to $6.19 \mathrm{mg} / \mathrm{m}^{3}$, average - from 10.8 to $4.2 \mathrm{mg} / \mathrm{m}^{3}$, welding aerosol maximum values from 26.01 to $2.58 \mathrm{mg} / \mathrm{m}^{3}$, average - from 15.02 to $1.23 \mathrm{mg} / \mathrm{m}^{3}$, as well as the iron and manganese oxides. Also the decrease in the maximum values of the level of noise from 105 to $86 \mathrm{dBA}$ and vibration from 121 to $117 \mathrm{~dB}$ is observed.

After the lean production implementation the most of working places (31.8\%) is characterized by the compliance of the working conditions with class 3.1 (fig. 3).

It is very important that the share of working places with class 3.4 decreased from 13.4 to $1.9 \%$ and class 3.3 from 47.3 to $20.6 \%$. The share of la- 
bor class 3.2 remained quite high (27.1\%), as well as the share of working places with class 3.1 increased - from 10.7 to $31.8 \%$, but it is explained by decreasing the number of working places with classes 3.3 and 3.4 and redistribution of the part of them to classes 3.1 and 3.2 with simultaneous redistribution of the part of working places of this class to class 2.0.

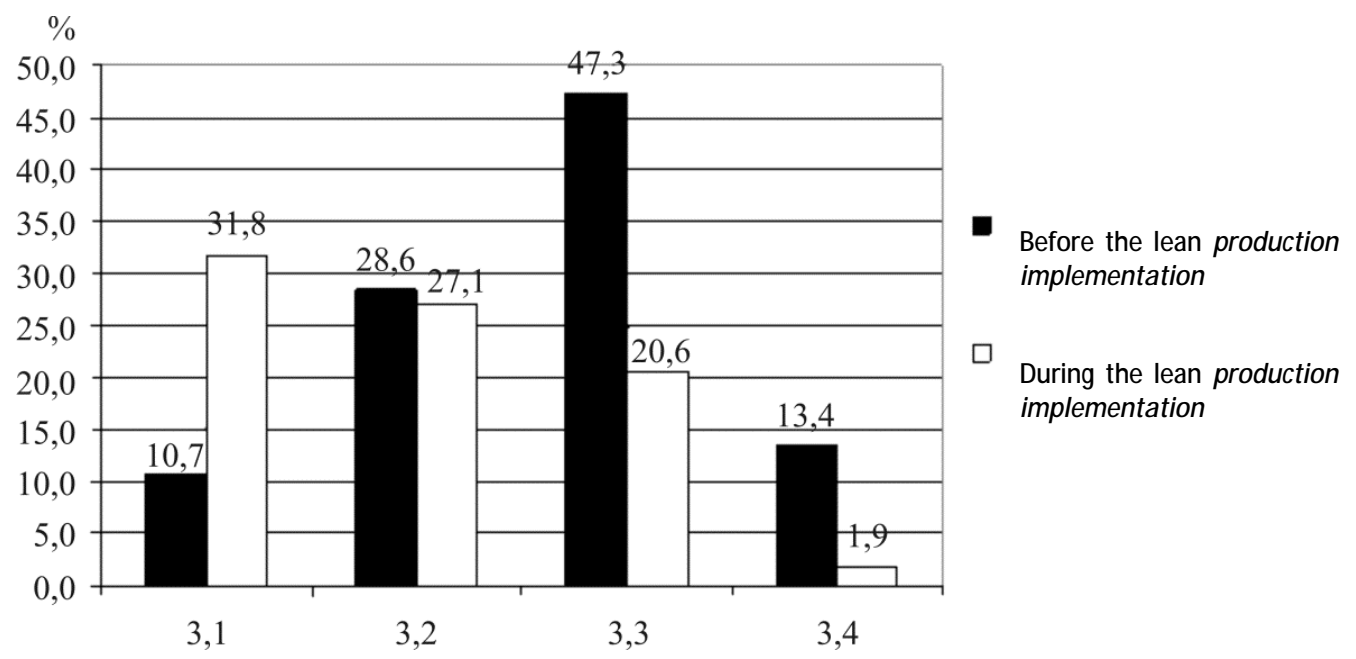

Fig. 3. Specific weight of working places under the class of harmfulness before and after the lean production implementation

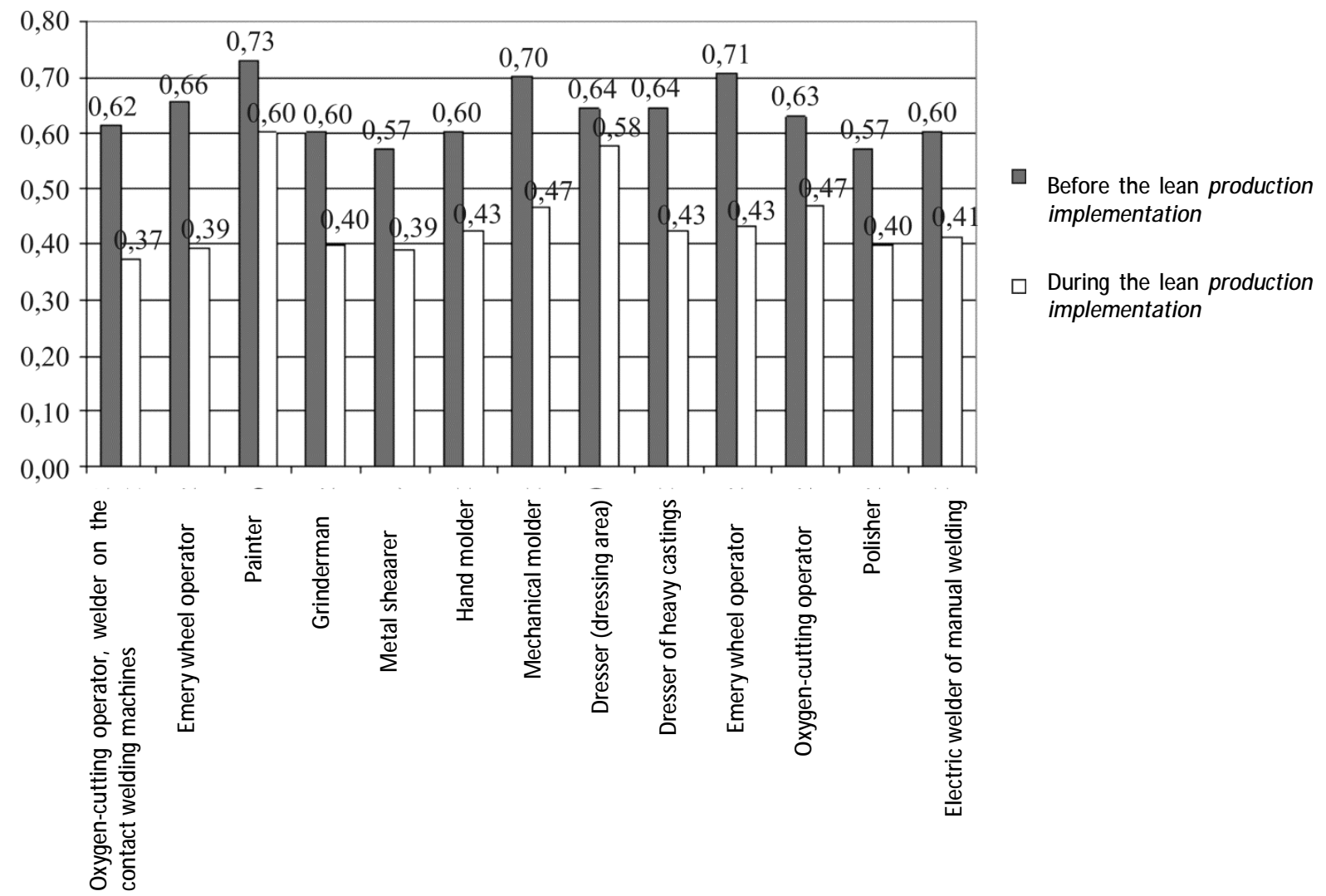

Fig. 4. Comparative analysis of the individual occupational risk (IOR) indicators before and after the lean production implementation

Therefore, the most harmful class 3.4 after the lean production principles implementation amounted to $1.9 \%$ of working places that is significantly lower than before the implementation
(13.4\%). Decrease in the share of working places with the most harmful working conditions (3.3 and 3.4) occurred mainly due to solving the critical labor protection issues which resulted in decreas- 
ing the impact of the occupational risk factors chemical factor and severity of labor in the frame and body shop (professions of welders and oxygen-cutting operators), chemical factor and noise (emery wheel operators); at the working places of the coach assembly shop (professions of painter due to decreasing the impact of chemical factor, metal shearer and grinderman due to decreasing the severity and intensity of work); vibration at the working places of casting shop (professions of painter - due to decreasing the impact of chemical factor, molder - vibration, dresser - noise). Herewith, the individual occupational risk indicators for these professions decreased by 1.12-1.67 times (fig. 4).

Together with it, the professions of cupola melter and smelter in the casting shop due to the specific character of foundry production remain the most harmful under the working conditions (class 4) among all the professions of the enterprise.

The number of working places with the harmful working conditions (classes 3.2 and 3.3) under the noise, vibration and chemical factor is decreased in the cold press shop.

\section{Conclusions:}

1. The working conditions for workers of the leading shops of coach-building production (frame and body, coach assembly, casting and cold press shop) are assessed as harmful and hazardous, forming the risks to the health (class 3 and 4). The profile (structure) of occupational risk depends on the peculiarities of working conditions at the certain shop and is represented by the leading contribution to its value in the casting shop from the heating microclimate $(22.2 \%)$, impact of chemical factor $(21.5 \%)$ and noise $(20.5 \%)$; in the frame and body shop - severity of labor $(28.2 \%)$, chemical factor $(18.3 \%)$, noise $(15.5 \%)$; $\mathrm{n}$ the coach assembly shop - chemical factor (24.1\%), severity of labor $(18.8 \%)$, noise $(15.5 \%)$; in the cold press shop noise $(29.5 \%)$, chemical factor $(28.2 \%)$, vibration (15.4\%).

2. Based on the ranking of professions under the integral indicator of harmfulness (HI) and haz- ard of working conditions the professions of the highest level of hazard and harmfulness (HI>30, highly hazardous harmfulness, rank 1) include the cupola melter and metal caster of the casting shop $(\mathrm{HI}=36)$, at the leading contribution to the indicator of harmfulness of the heating microclimate characteristics $(74.4 \%)$ (class of working conditions -4$)$; hazardous level of occupational harmfulness (HI from 15 to 30, rank 2) includes the painter (coach assembly shop), electric welder of manual welding (frame and body shop), metal cleaner (casting shop), emery wheel operator (cold press shop), mechanical molder (casting shop), boxman (casting shop), electric welder on the automatic machines (frame and body shop) - HI from 15 to 24 points. Herewith, for each of these professions the leading risk factor was different (chemical factor, severity of labor, noise, vibration, intensity of work), and its contribution to the value of the occupational harmfulness of profession varied from 34.8 to $59.3 \%$.

3. Practically all the professions of the main shop subdivisions of the coach-building production, taking into account the complex impact of the working process factor and risk of traumatism, belong to very high risk (from 0.4 and more), at the highest indicators of the individual occupational risk for the professions of metal caster (0.90), cupola melter (0.81), metal cleaner (0.79) in the casting shop; electric welder of manual welding (0.79), emery wheel operator (0.79), mechanic on the assembly of metal structures $(0.78)$ - in the frame and body shop; emery wheel operator $(0.78)$ - in the cold press shop that evidences the necessity of the fundamental improvement of working conditions.

4. The step-by-step implementation of the lean production principles in relation to the labor protection at the pilot areas allowed for decreasing the share of working places with class 3.4 from 13.4 to $1.9 \%$, with class 3.3 - from 47.3 to $20.6 \%$ that had the positive impact on the indicators of the individual occupational risk for a number of main professions which decreased by $1.12-1.67$ times.

\section{References}

1. Borisov N.A. Chelovecheskij kapital i programmno-celevoj podhod v formirovanii zdorovogo obraza zhizni naselenija regiona [Human capital and target-oriented approach to creating a healthy lifestyle of the population of the region]. Finance. Economy. Strategy. 2013, no. 12, pp. 26-29.

2. Mamchik N.P., Sisev V.A., Borisov N.A. Uslovija truda i sostojanie zdorov'ja rabotajushhih v aviastroitel'noj otrasli [Working conditions and health status of workers in the aircraft industry]. Ed. A.I. Potapov. Voronezh, 2004. $184 \mathrm{p}$. 
3. Measured N.F., Prokopenko L.V., Simon N.I., Nizyaeva I.V., Nazarov S.G., Zhuravlev E.A., Kondrovo N.S., Stepanov E.G., Fassik P.M., Tsyrulin A.V., Andreev E.E., Ignatova E.N., Grigorieva C.M. Metodicheskie rekomendacii «Metodika rascheta individual'nogo professional'nogo riska v zavisimosti ot uslovij truda i sostojanija zdorov'ja rabotnikov» [Guidelines «Method of calculation of individual professional risk depending on working conditions and workers' health»]. Moscow, 2012. 29 p.

4. Simon N.I., Kondrovo N.S., Andreeva E.E., Ignatov E.N. Ocenka individual'nogo professional'nogo riska na predprijatijah aviacionnoj promyshlennosti [Evaluation of the individual professional risk to aviation industry]. Materials X All-Russian Congress «Profession and Health». Moscow, 2011, pp. 448-450.

5. Razrabotka metodiki integral'noj ocenki uslovij truda na rabochem meste s uchetom kompleksnogo vozdejstvija proizvodstvennyh faktorov s razlichnymi klassami vrednosti (gigienicheskaja ocenka uslovij truda, ocenka travmobezopasnosti, ocenka obespechennosti SIZ) na osnove avtomatizirovannoj obrabotki dannyh [tekst]: otchet o NIR (zakljuch.) [Development of the method of integral evaluation of working conditions in the workplace, taking into account the complex influence of production factors with different hazard class (hygienic assessment of working conditions, evaluation of injury prevention, evaluation of security PPE) on the basis of automated data processing [text]: research report (agreement)]. JSC "Institute of Klin and working conditions" OLS-set "; hands. Kosirev O.A.; performers Kosirev O.A., Swirl S.V., Ivanov V.V. [And etc.]. Wedge, 2008. 102 p.

6. Simon N.I., Nizyaeva I.V., Nazarov S.G., Zhuravlev E.A., Kondrovo N.S., Stepanov E.G., Fassik P.M., Grigoriev S.E., Andreeva E., Ignatov E.N, Tsyrulin A.V., Mazitova N.N. Sravnitel'nyj analiz rezul'tatov ocenki professional'nogo riska na osnove razlichnyh metodicheskih podhodov [Comparative analysis of occupational risk assessment based on different methodological approaches]. Occupational Medicine and Industrial Ecology. 2012, no. 1, pp. 13-19. 